\title{
Co-evolutionary dynamics in strategic alliances: the influence of the industry lifecycle
}

\begin{abstract}
This study examines the application of the co-evolution literature to strategic alliance formation in SME's in the UK and Australia in two differing industries at different stages of the industry life-cycle. Extending the framework developed by Das and Teng (2002) and that of Wilson and Hynes (2009), it engages with wider industry and environmental characteristics present in these two countries, specifically examining whether different theories of alliance formation are better suited to different stages of an industry life cycle. The issues discussed above are explored and developed through the use of a qualitative case study approach using empirical evidence from SME's in the UK and Australia in two differing industries. Findings indicate strong resource-based drivers for alliance formation in both industries, with firms dependent on the co-evolution of their alliances and indeed selected by the results of their alliance participation. However, differences emerge in the strategic use of alliances in these two industries. The influence of the stage of the industry life cycle on this is discussed.
\end{abstract}

Key words: Co-evolution; industry life-cycle; case study; strategic alliances; organizational strategy. 


\section{Co-evolutionary dynamics in strategic alliances: the influence of the industry lifecycle}

\section{Introduction}

Industry dynamics impacts firm strategy and survival, and understanding which firms will succeed and whether firms should compete or cooperate at different stages of the industry life cycle is important both to managers and to theorists. Most literature about firm strategy and performance approaches this issue by examining the strategy, and performance of single firms. Yet with the increasing reliance on strategic alliances and networks, firms are also increasingly dependent on other firms for their own performance; a better understanding of how firms behave and change simultaneously is therefore crucial. Co-evolution (where species change at the same time to mutual advantage) has long been documented and argued within the scientific academic community and has recently been applied to industry $[1,2,3,4,5]$.

This study briefly reviews the current research on co-evolution in industry, and examines the application of this theory to the way in which firms form, perform, compete and change within alliance relationships. The importance of the industry life cycle is examined to explore whether co-evolution is a better explanation of change at certain stages of the industry life cycle. A framework outlining the key environmental factors affecting alliance formation and change, together with an assessment of how well coevolution is being seen at each stage of the industry life cycle is developed. These issues are developed through the use of a qualitative case study approach using empirical evidence from SMEs in the UK and Australia in two differing industries. This paper extends the work of Volberda and Lewin [3] who extensively critiqued the use of singletheme explanations for explaining the adaption and selection of firms and strongly called for the need for joint outcomes of intentional adaptation, and that of Wilson and Hynes [5] which delineated the underlying constructs and assumptions of evolution and coevolution in greater depth. Pyka [6] also explicitly suggests that a better understanding of alliance formation over the different stages of the ILC is essential.

\section{Background}

\subsection{Strategic Alliances}

Strategic alliances include a wide range of cooperative relationships [7] covering a variety of contractual forms from joint equity ventures to contracts and less formal 
working agreements. Over the last two decades there has been unprecedented growth in the number of these inter-firm alliances [8,9]. Some of this change towards co-operative structures has been stimulated by the increased globalization of markets, decreasing product life-cycles and increasing rate of technological development. This proliferation of strategic alliances has been accompanied by an increasing stream of research by scholars who have examined many of the causes and consequences of alliance formation $[10,11]$.

Traditional models of firm behavior are difficult to apply to this co-operative behavior [7,12] although theories previously used to understand strategic alliance formation include transaction cost economics $[13,14]$; resource based theory $[15,16]$; and social structural explanations [17,18]. Whilst these are useful at explaining the reasons why organizations form alliances, they do not account for the mechanisms of change during the lifetime of the alliance. There is an increasing research stream focused on alliance developmental processes, although the understanding of these remains quite limited $[1,2,19]$. For example, although alliances are known to be highly unstable [1] it is still relatively unclear how, and why, change within alliances occurs and whether theories such as co-evolution would provide a better explanation of this change. Forming and competing using strategic alliances may change the way in which firms change, and compete, as well as changing the unit of selection from a single firm to possibly including the strategic alliance partner(s).

\subsection{Co-evolution and Strategic Alliances}

Early work using co-evolution as an explanatory factor for change focused solely on the interaction between a firm and the environment [20,21], and the resultant simultaneous change was considered co-evolutionary. In addition, although the mechanism of change was proposed as co-evolutionary, the focus of this work was primarily on the firm as the unit of selection.

Later work considered that for co-evolution to occur the change need not be between firm and environment, but could also occur within two firms or between firms and strategic alliances. Applying the theory of co-evolution to better understand change in firms and their strategic alliances assumes that change may occur in either the dyad of alliance partners or in the alliance-partner dyad simultaneously. The complexity of strategic alliances and their "parent" firm results in each element evolving separately as well as co-evolving interactively [1] and for co-evolution to occur, the population should consist of heterogeneous firms that have learning capabilities and are able to mutually influence each other; yet very few empirical articles exist examining co-evolutionary change [3]. 
Whilst change can be co-evolutionary, the unit of selection as a result of this change has generally been considered to be the individual firm [22]. Although Wilson and Hynes [5] introduce the notion of simultaneous success or failure of two or more firms as a result of co-evolution, prior research has generally focused on a single firm's advantage being brought about by simultaneously changing with the environment or other firms; few if any studies addressed the advantage conferred on the dyad or group as a result of coevolution. Various studies of strategic alliances have included a time dimension [23,24], yet Koza and Lewin [2], argue that "singularly absent from the literature are studies of the evolution of alliances over time, as they co-evolve with the changing strategies of firm, evolving industry strategic practices and the changing regulatory and institutional environment." (pp. 258). They argue that alliances are not only embedded within the strategy portfolio of each partner, but importantly the wider environmental characteristics.

This adaptive co-evolutionary response to a changing environment can therefore be framed within the industry lifecycle framework. To date, relatively little attention has been paid to whether firms co-evolve and survive differently at differing points of their life cycle. Furthermore it is not well understood whether a firm is, at various times of its life cycle subject to such upheaval, that a strategy of co-evolution reduces its risk, and hence increases its survival rate. Alternatively, if co-evolution occurs in some firms and strategic alliances within an industry, then this might in turn affect the selection criteria of the remaining population within this industry.

\subsection{The Industry Lifecycle Framework and Strategic Alliances}

The industry lifecycle framework (ILC) describes the evolution of an industry, including progressive stages of growth, maturity and decline. Proponents of the framework argue that industry characteristics at each stage require an appropriate organisational structure, decision-making process and strategy. The life cycle literature has largely focused predominantly on firms entering or exiting an industry [25,26], and largely on the assumption that firms enter the market alone, compete alone and are selected alone. Williamson [14] built on Schumpeter's [27] early work, which described the industry life cycle as several stages including the early or exploratory stage, an intermediate development stage, and a mature stage with periods of destabilised change in between.

This context influences the nature and extent of a firm's external resource needs and resource acquisition behaviour [28,29]. Although Covin and Slevin [30] suggested a strong link between management practices and industry life cycle, suggesting that the strategic posture or overall competitive orientation of firms changes over the firm life 
cycle, it is not well understood whether a firm is, at various times of its life cycle more likely to form strategic alliances although the motivations for forming alliances may also be different at different stages of the industry life cycle. Van den Bosch et al [31] suggest that at varying life cycle stages the knowledge absorptive capacity of firms change and that firms in turbulent (as often seen in emerging) industry environments are more likely to dedicate efforts to increasing their absorptive capacity, which could include forming strategic alliances.

The early or emerging stage typically has a high degree of uncertainty and the primary focus of this stage is the growth of the firm; thus whilst technology is developing and no clear standards or platforms are adopted in the market, alliances might be formed to access technology. Indeed the emerging stage of an industry is shaped by uncertainty; in technology, in the market, and in terms of setting behavioural norms [32]. Work on emerging industries tends to confirm the idea that there are a high number of small firms at the early stages of industry development, and that after some time of technological and market adjustment, the industry reaches some degree of legitimacy $[32,33]$.

Streams of literature on emerging technologies tend to focus on the overall adoption of a technology rather than the growth and selection of firms but also suggest that the adoption of certain standards or norms will lead to the selection of firms which have adopted this standard [35]. In fact "keeping a foot in the door" for new technologies has long been seen as a motivating factor for large incumbent technology firms to form many strategic alliances with small firms in emerging technologies because they believe that by retaining options in each of the new emerging technologies, they will effectively be coselected for the winning technology [35,36]. Whilst ILC research has often focused on the importance of technology as the key influential force, the strategic alliance literature is rich with explanations of cooperative strategies in emerging industries (biotechnology, computing etc). Pyka [6] suggests that strategic alliances in emerging industries are very closely linked to technological emergence. However other research has found the focus of alliances in emerging industries to be only partially focused on technology, with access to new markets and finance equally important [37].

Firms often work co-dependently at this stage, often as a result of resource deficiency and the process of working together in a rapidly changing environment can result in concurrent change within the organizations. Thus, it would seem that at emerging stages of an industry, where many small players enter the field, along with a small number of larger firms, co-evolution may be a better explanation for change, and co-selection is a better explanatory variable than evolution and individual selections. Likewise, the rapid change and high levels of uncertainty together with resource codependence mean that firms may be selected together for success or failure, therefore: 
P1. The success or failure of firms in the emerging period of an industry life cycle is best explained by co-evolution and co-selection.

Klepper [25] suggests that innovation is higher in the initial phase of an industry life cycle, followed by a period of "shakeout". This period of shakeout is often when many firms fail. This intermediate stage is the time at which marketing and manufacturing techniques are sharpened and at this point in the life cycle, the focus of alliance might be motivated towards more marketing focused alliances. These established firms and industries have been the focus of most strategy literature; these are firms which scan and interact with their environment, but can set their own strategy and are selected for on their own characteristics. Much of the mainstream strategy literature $[38,39]$ focuses on this market stage and is based on the managerial assumptions of firms setting strategy as a result of environmental scanning and firms being selected for at individual level. Baum and Singh [40] suggest this to be a form of diffuse co-evolution which is explained as concurrent changes occurring but as a result of one or more firms evolving in response to one or more other populations or their environments, but not direct co-evolution. Therefore:

P2. The success or failure of firms in the growth and maturity stages of an industry life cycle are best explained by the theory of evolution and individual firms as the unit of selection.

Finally industries in decline are typified by a market demand that is relatively static, or reducing, concurrent to the number of number of active firms reducing. At this point, for example, complete supply chains may be selected for simultaneously; companies supplying the wrong firm at the final end of the supply chain may fail at the same time as this firm fails. There is little chance for these firms to find other markets for their products or services as the structures supporting the market are already established and relationships mature. Mergers and acquisitions are frequent at this stage of the life cycle [25]. In addition, companies within the supply chain, or previous competitors may work together at this time to ensure that the group is selected for, rather than the individual firm. The overall market size may decrease or remain stable, therefore the only strategy for growth is increasing market share [25]; and firms may envisage advantages to collaboration in terms of access to declining markets, therefore:

P3. The success or failure of firms in the declining stage of an industry life cycle is best explained by co-evolution and co-selection. 
The characteristics of the different industry life cycle stages and the implications for co-evolutionary research are presented in a summary framework in Table 1. The grey sections refer to the propositions outlined above which are explored in the case studies presented.

Table 1. Framework for Coevolution within the Industry Life cycle

\begin{tabular}{|c|c|c|c|c|}
\hline & Introduction & Growth & Maturity & Decline \\
\hline $\begin{array}{l}\text { Industry } \\
\text { Population }\end{array}$ & $\begin{array}{l}\text { Population } \\
\text { unstable; Many } \\
\text { small firms with } \\
\text { high need for } \\
\text { venture capital }\end{array}$ & $\begin{array}{l}\text { Population remains } \\
\text { unstable and } \\
\text { growing rapidly but } \\
\text { rules of competition } \\
\text { beginning to be } \\
\text { established; } \\
\text { Shakeout of firms }\end{array}$ & $\begin{array}{l}\text { Firms compete } \\
\text { intensively as market } \\
\text { stablises. Several } \\
\text { dominant firms } \\
\text { dominate the market }\end{array}$ & $\begin{array}{l}\text { Population unstable } \\
\text { and declining in } \\
\text { number }\end{array}$ \\
\hline $\begin{array}{l}\text { Industry } \\
\text { structure }\end{array}$ & $\begin{array}{l}\text { No established } \\
\text { supply chain so } \\
\text { many options } \\
\text { possible }\end{array}$ & & $\begin{array}{l}\text { Changes in supply } \\
\text { chain population } \\
\text { ecology have } \\
\text { massive impact on } \\
\text { producers and } \\
\text { consumers; can lead } \\
\text { to multilevel co- } \\
\text { evolution and } \\
\text { changes in entire } \\
\text { populations }\end{array}$ & $\begin{array}{l}\text { Changes in supply } \\
\text { chain population } \\
\text { ecology have massive } \\
\text { impact on producers } \\
\text { and consumers, can } \\
\text { lead to multilevel co- } \\
\text { evolution and changes } \\
\text { in entire populations }\end{array}$ \\
\hline Technology & $\begin{array}{l}\text { No established } \\
\text { technology } \\
\text { standards; many } \\
\text { competing } \\
\text { technologies }\end{array}$ & $\begin{array}{l}\text { Establishment of a } \\
\text { dominant standard } \\
\text { or architecture }\end{array}$ & $\begin{array}{l}\text { One dominant } \\
\text { technology with } \\
\text { suppliers mostly } \\
\text { offering this }\end{array}$ & $\begin{array}{l}\text { Discontinuous change } \\
\text { might mean market is } \\
\text { replaced }\end{array}$ \\
\hline $\begin{array}{l}\text { Behavioural } \\
\text { norms }\end{array}$ & $\begin{array}{l}\text { No established } \\
\text { market norms or } \\
\text { behavioural } \\
\text { norms for } \\
\text { emerging } \\
\text { companies }\end{array}$ & $\begin{array}{l}\text { Establishment of } \\
\text { organisational and } \\
\text { industrial norms for } \\
\text { competing }\end{array}$ & Established & $\begin{array}{l}\text { Norms and behaviours } \\
\text { change due to } \\
\text { reducing market } \\
\text { demand }\end{array}$ \\
\hline $\begin{array}{l}\text { Drivers for } \\
\text { formation of } \\
\text { strategic } \\
\text { alliances }\end{array}$ & $\begin{array}{l}\text { Resources (small } \\
\text { firms) } \\
\text { Access to } \\
\text { technology } \\
\text { (larger firms) } \\
\text { Access to } \\
\text { markets }\end{array}$ & $\begin{array}{l}\text { Resource sharing } \\
\text { Risk reducing }\end{array}$ & $\begin{array}{l}\text { Resource sharing } \\
\text { Risk reducing }\end{array}$ & $\begin{array}{l}\text { Changing patterns } \\
\text { within the supply } \\
\text { chain } \\
\text { Reduction in demand } \\
\text { Requirement to lower } \\
\text { costs }\end{array}$ \\
\hline $\begin{array}{l}\text { Mechanisms } \\
\text { of change } \\
\text { predicted }\end{array}$ & $\begin{array}{l}\text { Firm- } \\
\text { Environment } \\
\text { Firm-firm } \\
\text { Firm-alliance } \\
\text { Co-evolution a } \\
\text { stronger } \\
\text { predictor than } \\
\text { evolution (P1) }\end{array}$ & $\begin{array}{l}\text { Firm-Environment } \\
\text { Evolution a } \\
\text { stronger predictor } \\
\text { than co-evolution } \\
\text { since firms } \\
\text { established with } \\
\text { own strategic } \\
\text { direction (P2) }\end{array}$ & $\begin{array}{l}\text { Firm-Environment } \\
\text { Evolution a stronger } \\
\text { predictor than co-- } \\
\text { evolution since firms } \\
\text { established with own } \\
\text { strategic direction } \\
\text { (P2) }\end{array}$ & $\begin{array}{l}\text { Firm-Environment } \\
\text { Firm-Firm } \\
\text { Firm-alliance } \\
\text { Co-evolution } \\
\text { occurring through } \\
\text { strategic alliances; } \\
\text { alliances essential to } \\
\text { maintain viability (P3) }\end{array}$ \\
\hline Unit of & Selection unit & Unit of selection & Growing trend for & Multiple: Firms, \\
\hline
\end{tabular}


change and selection proposed variable and can more focused on include firms, individual firms dyads and networks (P1) selection to involve dyads, supply chains, more than 1 firm (P2) alliances. (P3)

\section{Methodology}

The findings reported here are part of a wider research enquiry, exploring processes of strategic alliance formation and determinants and measures of successful relationships. The research examines the application of co-evolution theory to strategic alliance formation in SME's in the UK and Australia in two differing industries; namely the UK fresh produce industry and the Biotechnology industry in Australia. Extending the framework developed by Das and Teng [1], it engages with wider industry and environmental characteristics present in these two countries.

The issues discussed above are explored and developed through the use of a qualitative case study approach, allowing an understanding of a 'complex, holistic picture' [41]. Data was collected from secondary sources; extensive semi-structured interviews with one or more members of the senior management team of the UK and Australian businesses on site; participant observation in meetings with overseas partners in three European countries; and the use of records and follow-ups with one or more senior members of each business over a period of eight months. The multiple sources of data typically used in case study research allow for a more holistic and in-depth understanding than other single method qualitative approaches [42] and encourage a more contextually based understanding of social phenomena [43].

The use of in-depth interviews allows the researcher to gain an insight into these factors in a way that could not be achieved through a quantitative survey, building up a picture of inter-connection rather than a list of single key factors. The flexibility of semistructured interviews allows for the possibility of unspecified factors to emerge in the interviews and their importance to be discussed in depth. The sensitivity of the area of the research also informed the methodology. Respondents were being asked in-depth questions about the purpose and scope of their strategic relationships with other companies; their selection criteria, operating procedures, goals and objectives; the costs and benefits of the alliances they were in, and how all this fitted into their current and future strategic operations. These are sensitive areas and have become increasingly so with the increased levels of competition. The information obtained from all respondents was only obtained after guarantees about the confidentiality of any disclosures; most of the interviews were conducted in a private office with only the researcher and the interviewee present. By using one-to-one in-depth interviews the researcher was able to develop a close rapport and build trust so that the interviewee was assured of confidentiality and was able to speak freely. It is highly unlikely that the levels of 
disclosure and the depth of information obtained would be obtained in a mail survey where this level of trust had not been engendered. Each interview varied in length, lasting between one to three hours. The interviews were conducted at the respondent's place of work. Immediately after the interview, the taped transcripts were checked and the interview notes were read to ensure there were no areas of ambiguity or uncertainty.

The samples for the UK and Australian interviews were chosen on a non-probability judgement basis. The UK data was stratified in terms of geographical area and produce type to obtain a spread of producers across the country and covering the main produce types. A range of firm size and ownership profiles was chosen. In total 33 UK producers were contacted and 20 interviewed. The Australian sample was selected after inviting all listed Biotechnology firms within Queensland. Many declined to be interviewed, and the final sample included 13 organisations which all gave interviews. Although a relatively small sample, this is consistent with other qualitative research samples [44]. Indeed, Patton [43] argues that "the validity, meaningfulness, and insights generated from qualitative inquiry have more to do with the information richness of the cases selected and the observational/analytical capabilities of the researcher than with sample size."

\section{Industry Case Studies}

\subsection{The Australian Biotechnology Industry - an emerging industry?}

The Queensland Government is committed to establishing the State as the centre of excellence in biotechnology in the Asia Pacific and will employ over 16,000 people and generate $\$ 4$ billion in revenues to an industry worth $\$ 20$ billion by 2025. Queensland's biotechnology industry currently comprises around 88 companies and 68 biotechnology-related research institutes. Combined, these organisations employed over 5,200 people and generated an estimated \$690 million in revenues in 2004/05 [45]. In addition, the "smart state" strategy encourages particular types of biotechnology industry; primarily those focused on human health, and several strategies have been put in place to encourage start-ups including cooperative networks, although the source of financing for most biotechnology companies in this region, remains commercial venture capitalists. However many start-ups are single product or service companies, and since the commercialisation of biotechnology products can be between 5 and 20 years after discovery, many small companies are found in these early development stages, the companies included in this study largely fell into this category.

Most companies interviewed were small start ups with less than 10 employees; some were still incubator firms, but others had been around for longer. All had formed 
strategic alliances. The ranged from $\mathrm{R} \& \mathrm{D}$ development projects, licensing in/out agreements, clinical trials at varying degrees, and upscaling to commercial production of new materials. Some alliances spanned marketing and finance as well, although these were less common. A strong recurring theme in this emerging industry dataset was the motivation of most alliance formation which was clearly in the majority of cases, purely resource driven. These small biotechnology firms did not have enough resources and actively sought out a range of strategic alliances including suppliers, collaborators and large companies who could act as guarantees of reputation/ quality that would then lead them to better outcomes in different ways; producing products, testing drugs; and raising venture capital. These firms all confirmed that they could not survive on their own and formed strategic alliances in order to survive; an example of this is:

"In Australia, they [other companies] don't have the resources to set up their own labs in general; they are one man operations or two at best so they have to outsource everything so therefore we are very good partners to work with"

Every firm interviewed had multiple alliances and these had, by the nature of being involved in these alliances, changed the firms; in some instances they led to new alliance opportunities, showing evidence of co-evolution at several levels; between firms; between firms and the alliance; and between alliances, firms and the environment. Some showed evidence of changing with their alliance partners over time, but others used alliances sparingly and for fixed portions of time to help with resource needs:

$Q$ : And do you think that relationship with $X$ has led to other opportunities that you maybe would not have had without it?

A: "Well it is interesting, they have actually brought some clients to [Firm A] and now that we are doing the bioanalyticals for [Firm A] we are actually now working more closely with [X] so we had an alliance with them, and another alliance with them, and now we have got the three-way thing happening and it is interesting, [Firm A] have a consultant who brings a lot of clients to them and now we are starting to work with their consultant as well, so it is interesting how things evolve. It starts off here but then it mushrooms"

The need for survival was also expressed in other ways; some firms saw alliances as ways to increase their survival changes by "hedging their bets" on new emerging technologies:

"Because you cannot pick the winners on early stage stuff you are better off actually having a very large portfolio (of alliances). So we have found that by 
working with them they don't want to invest in building a small team of their own because that is as much as their resource could be."

For other firms, being part of the "right" strategic alliance gave credibility to the company and they believed this would lead to increased Venture Capital (VC) funding opportunities. A slightly surprising driving force behind the structure of the firms, and the way in which they worked together or co-evolved was the pressure from VCs to exit the industry:

"One of the other reasons for it is the venture capital industry here and they are very, very focused on exits, and they want exits within a five-year timeframe usually and at the very outside, somewhere between 5 and 10, and if you are doing pharmaceutical development then you are not going to get all that far in 5 years .....It does not create large companies...... It is just all about money, it is all about investment, it is really not about long-term economic development at all"

Given that evolution and co-evolution are about mechanisms to change, and adapting to the environment, the analogy given by these two theories fails to explain a common phenomenon in this industry; that is of having an exit strategy at a fairly early age of the company. However even when early exit was seen as the end point for a company, alliances were seen as a mechanism to achieve this, showing that in this industry co-evolving to form alliances and co-evolving to make these alliances worked ended in the end of one company through a merger to another:

"The exit strategy for $X$ is a trade sale and that will either happen in the next two years or $X$ will disappear. It is a finite end to the whole thing and we have the technology. We have driven it about as far as it needs to go, we don't do much in the way of $R \& D$ we just try to sell the product and we either do or we don't. I mean if we don't then we will file the patent so to speak and keep it going for the moment but there is enough candles to keep the patents alive, because the technology may not be seen as desirable this year but it may be seen as desirable in a couple of years time"

This dependence on venture capital was significant, but perhaps more so, in this particular industry was the difficulty in scaling up from discovery to testing (clinical trials) and then scaling up once more before commercialisation. The sheer scale of sizing up appears to be the impetus for exiting the industry and selling off the intellectual property. Another company said: 
"But I think, you know, there are lots and lots of small companies for whom \$1 Million $\$ 2$ Million gets them a prototype and a proof of concept and another $\$ 5$ Million gets them convincingly close to the market and then they suddenly realise, you know what, to get manufacturing going and things like that we need $\$ 20 / \$ 30 / \$ 80$ Million where are we going to find that. Particularly in the last 6-9 months, and I suspect for the next 6 months, you would not turn to the public markets for raising that money. You really have to try to find a big company that is going, you know they are going to eat your lunch, but you know that is part of the deal you have gotta do."

This worked both for small biotechnology firms and the larger pharmaceutical firms that they partnered with; however it was clear that the respondent felt that the two firms did not "need" each other anymore; perhaps implying that there were stages of development which clearly showed co-selection but that this period was now passed. In this case the product in question had been through clinical trials and was reaching the commercialisation stages.

"That is an interesting question. I suppose it has because we probably don't need them now as much as we did. I mean they still don't need us in the sense that they can survive without us, their product would stand on its own, it is not on the market yet but it probably will be in the not too distant future. Our product does not need theirs anymore either but we would still prefer to go with them. In other words of the options available now there are more than there were then but as it still happens that is the best plan for us, I suspect, to do it, not least because they are now with a really big pharma now, which suits us because that is eventually where we see our product as targeted"

In summary, most if not all firms sought out alliances for mostly resource needs initially, although some subsequent alliances developed over time as a consequence of these initial alliances, and as a mechanism to try to change the selection process from firm to dyad. Most alliances showed changes over a period of time between the firms, the firm and the alliance, and the environment, the firm and the alliance. Sometimes this extended to locating and entering new alliances. Selection appeared to be early at the firm level - could the firm raise venture capital to continue or not? However some firms hinted that the relationships they had formed through alliances, increased the likelihood of gaining funding, and this showed a level of co-selection. The Biotechnology Industry within Australia is determined very much by its environment; the ability to seek funding and local government initiatives, and these external factors played a large role in determining which alliances were entered. 


\subsection{The UK Fresh Produce Industry - A mature / declining industry}

Changes in the UK retail food Industry over the last 20 years have had an important effect on the fresh produce sector in the UK with the emergence of a few key firms in the industry. The UK Fresh produce industry is now in a mature phase of the industry life cycle and the retail sector is dominated by 4 large firms: Tesco, Wal-MartAsda, Sainsbury and Morrisons. Tesco, the market leader has a 31\% share of the market, followed by Wal-Mart-Asda at $17 \%$, Sainsbury at $16 \%$ and Morrisons at $12 \%$. These multiple retailers have increased their share of the total market year on year. From 1994 to 1999 their market share grew by $14 \%$ from $63 \%$ to $77 \%$ [46]. Although there has been changes in the share allocation between the big players in the industry, the actual market share of the top 4 multiple retailers in total has not changed by than 1-2\% year on year over the last 10 years. Thus the industry has seen slowing demand at an aggregate level but changes in the share of that demand. The wholesale markets, traditionally the most important outlet for agricultural produce have decreased numerically and in relative importance [47]. By 2005 the dominant 3 retail chains accounted for $84 \%$ of all fresh fruit and vegetables sold in the UK [47].

Supplier firms not who cannot obtain access to the network of customers and suppliers dominated through these 4 players, have come under significant competitive pressure and many have exited the industry and the total number of farm holdings in the UK and the area used for farming have been declining steadily. Overcapacity and poor returns in the sector has led to some rationalisation and a reduction in the number of firms over the last few years. The total number of farm holdings fell from 60,600 in 2002 to 53,800 in 2008 [48]. This was accompanied by a fall in total production area from 3.25 million acres in 2002 to 2.67 million acres in 2007 [48]. Only 13\% of fruit growers and $7 \%$ of vegetable growers had sales of $£ 1$ million or more in that year and only 5 fruit and 60 vegetable growers had sales of more than $£ 5$ million. Whilst these larger growers were responsible for a disproportionate amount of total output in the industry, the majority of farm holdings in horticulture are small, specialist businesses, often operating on a regional basis for production and often specialising in particular areas of the market. The outcome of this is that each product area is dominated by a few large companies despite the numerically dominant small-scale holdings.

A large number of strategic alliance between growers (40\%) were between firms who had had prior trading relationships, which then developed into an alliance. Twelve others included firms learning about their potential existing partners through other existing trading relationships, such as wholesalers, suppliers of equipment and seed, agents and importers. None of the firms had had previous alliances with their partner, although this is largely to do with the fact that most firms had little alliance activity before these 
current alliances. Where alliances had been formed, these were largely seen as a survival mechanism of mutual dependence. The alliance itself also became a new organisational form, so whilst the firms still saw themselves as disparate entities in terms of their identity, they regarded the alliance as a form in its own right, as noted:

"There is great symbiosis. Both parties are as dependent on each other for things to work."

"Our partnership is an entity in its own right, separate from both ours and our partners' business....” and

The need for co-evolutionary change was described as the "flexibility" of the alliance to change with the changing objectives, resources and relative power of the partners was also a significant determinant of alliance success, as cited by others $[23,49$, 50]:

"The best alliances are unstructured, loose, not written down, but based on mutual trust and acceptance of each-others' position, point of view and efforts. That is what we have." and

"Our supplier has a business now that is worth 4 times what it was 3 years ago and it is still growing. Both of us are now very dependent on each other."

In three alliances the partners were looking for a significant increase in integration between the partner firms through investigating the options for a joint venture and one firm was actually in the process of setting up a joint venture. This can be explained as either an evolutionary process for the alliance, or a co-evolutionary process of the two firms. In these cases this change in structural form was driven by a need for increased control over the day to day running of the relationship:

"We have decided that we need to be growing in Spain. We are not seeing the improvements in cultural practices coming through as quickly as we would like. The reason we are doing it with (partner firm) is in part a hand-holding exercise. (Partner firm) have experience of what is going down in Spain and for the first few years it will be much better if we have them showing us the ropes...there are things that happen in Spain that wouldn't happen in other countries."

Where there were changes in the environment, alliances could falter. An example of this was changing requirements during supply seasons. For most of the year the source of product was clearly defined by the growing conditions in the countries concerned. Therefore the period when the UK partner needed their alliance partner to supply product 
was clearly demarcated. However, technological improvements in growing and storage techniques have meant that the crossover periods from end of season in one country and beginning of season in another are becoming increasingly blurred and longer in duration. This has meant that at these times alliance partners were both growing product that they wanted to supply to their end customer and therefore the dependence on each other has changed. The alliance between the two firms needed to change or co-evolve in this instance with changes in the environment:

"The key factor that is likely to affect our relationship is the ever lengthening seasons. We [Firm B] want to grow longer into the autumn and start earlier and our partners want to continue longer into the traditional UK summer season and start earlier in the autumn. This is likely to become a bigger issue."

The balance of needs was also affected when the focal firm was no longer necessary to provide the key resource driver for the partner firm, notably access to the UK market. Two firms had had experience of their partners trying to cut them out of the supply chain. For both of them this had led to the end of the alliance relationships:

"Partnerships can go wrong. We have had lots of experience of suppliers sending product to a more profitable customer or claiming not to have a crop. Trust is crucial."

In summary, the alliances in the fresh fruit industry showed a high degree of integration between the partner firms. The alliances formed to try to change the unit of selection, and as a mechanism for firm survival. Partners inputted resources and worked together on a continuing basis, evolving at both the alliance level, which often changed from its initial objectives and also resulting in changes within the originating firms. This shows simultaneous co-evolution between the firm and the alliance, and the firm and partner firm supporting Das \& Teng's [1] definition of co-evolution as different parts of a system evolving simultaneously and interacting with each other so that one partner's evolution is affected by another partner's evolution. In common with the biotechnology industry, there is evidence of these alliances evolving out of other relationships and these alliances themselves evolving both in terms of structure and of scope over time. The strongest driving force was environmental and firms reacted to environmental change by forming alliances, thus showing a degree of co-evolution. The alliance relationships also co-evolved in terms of scope and operations and in some instances in terms of new emerging structures, quite separate from those of the two firms. In this mature / declining industry, co-evolution through alliance formation and during the alliance lifespan was seen as a survival mechanism and the unit of selection was therefore changed to be the dyad, rather than the single firm. 


\section{Discussion and Conclusions}

This study set out to examine the ways in which firms form, perform, compete and change within alliance relationships, using two case study examples as rich in-depth perspectives of industries at different life cycle stages.

Within the emerging industry of Queensland Biotechnology, the industry and National norms appear to have predefined life cycles for this industry sector: instead of building companies that commercialise one product, and then move onto the next, the structure seems to define that companies establish, form alliances, co-evolve for a period of time, leverage the alliances and then find an exit strategy; this in some ways contradicts the underpinnings of the industry life cycle which suggests there is a shakeout based on market effectiveness and efficiencies. It would appear that firms in fact are established only to exist through this emerging industry period. During this time they are wholly dependent on the co-evolution of alliances; and are indeed selected largely by the results of their alliance participation. The need to use strategic alliances to survive the first emerging stage of product, market or company growth was clear. No single firm contacted could work alone. Whilst the case study supports P1 and co-evolution as an explanatory of change, the unit of selection is less clear. Without the alliances the companies would have failed immediately as they lacked resources; yet it is unclear in this study whether the dependence on any one firm resulted in co-selection.

The instability of these alliances support others findings [2,54]. Koza and Lewin [2] argue that at this early stage of the industry lifecycle this instability reflects the higher risks of exploration and high failure rates, but also importantly, the successful conclusion of alliance formation strategy, as is seen here. In this way the dissolution of the alliance is not a reflection of failure, rather the success of the individual firm and alliance goals. In the biotechnology industry these alliances were conceived as a relatively short-term strategic form to get a conceptual idea to the next stage of development. Furthering the concept of (in)stability, these alliances actually had dissolution built into them. Thus supporting findings from Koza and Lewin [2], the instability of these alliances were "endemic to their strategy, structure and functioning".

Biotechnology is an industry with characteristics common to other high-technology industries; because there are few direct competitors in the start-up stage and the development stages are long and costly [51]. Selection is a long term process, and to get a single drug to market might take many strategic alliances, mergers and / or acquisitions, so determining whether the firms working together had been selected together would require longitudinal and complex data. This issue with legitimacy and establishing order 
in emerging industries is common [51,52]. In developing this model, the paper challenges the claim by McKelvey [53], that co-evolution can only take place where the population of firms consists of heterogeneity as firms in this case study were of differing size and experience.

For the fresh produce industry, an industry at a mature and arguably declining stage; the firms interviewed are those remaining after a shakeout; many small firms have already exited the industry or have been forced to find alternative channels for their product. Alliances were being formed initially as a mechanism for survival, but once formed, the alliance became an essential part of the firm, which not only saw coevolution occurring between firms but between firms and alliances. Co-evolution was seen in terms of scope and operations and in some instances in terms of new emerging structures, quite separate from those of the two firms. The individual firm strategy and the strategic intent for the alliance were seen to co-evolve with changes in the wider industry environment supporting the findings of Koza and Lewin [54]. Supporting Arino and de la Torre [55], co-evolution occurred at the levels of firm and alliance strategy and as a result of feedback from alliance outcomes, the strategy of the individual firms changed.

In most cases there was a strong commitment to the strategic alliance with a sense that this was a structural form that could stay as such for an indefinite period. This stability of alliance form is surprising given extant research as discussed above that argues that alliances are inherently unstable. In this later stage of the industry lifeycle, alliance instability has been found to be due to increasing divergence in the strategic goals of the alliance partners over time $[2,54,56]$ and indeed in the few cases where alliances had ended or were in the process of ending it was due to a change in the balance of resource needs between alliance partners and ensuing divergence in strategic goals. However the overwhelming positive feelings towards alliances in the fresh produce industry suggests that firms which made the co-evolutionary change to alliances succeeded and this was confirmed by the views of the firms themselves who attribute their success to the alliance. Therefore overall there was support for both elements of P3 in that in this declining industry, evidence of co-evolutionary change and co-selection was seen.

These findings are summarised in Table 2, which builds on the framework developed in Table 1 and summarises the findings of this study. Clearly in these two case studies, the mechanism of selection had become more than individual firms, the strong dependence on alliances suggests a co-dependence best described by co-evolution rather than evolution. The findings show strong resource-based drivers for alliance formation in both industries under study. Firms were shown to be dependent on the co-evolution of 
their alliances for their continued existence and indeed were selected by the results of their alliance participation. However, this study also shows differences in the strategic use of alliances in these industries. For the firms in the fresh produce industry cooperation through alliances was a key determinant of survival. Firms survived because they changed together and a co-evolution strategy was seen to reduce risk and increase survival rates. Co-evolution of firms in this industry can be shown to be occurring at multiple levels with changes in scope and structure and in some cases new evolving structures quite separate to the two firms in the alliance. In the biotechnology industry co-operation was evident by multiple strategic alliances. It was typified by many small firms who formed alliances to access resources and achieve legitimacy. The nature of being in these alliances changed the firms yet the ways they used these alliances differed. Some showed evidence of co-evolving, yet others used alliances sparingly and for fixed portions of time to help with resource needs.

Table 2 summary of Results

\begin{tabular}{|c|c|c|c|c|}
\hline & Introduction & Growth & Maturity & Decline \\
\hline $\begin{array}{l}\text { Mechanisms } \\
\text { of change } \\
\text { predicted }\end{array}$ & $\begin{array}{l}\text { Firm- Environment } \\
\text { Firm-firm } \\
\text { Firm-alliance } \\
\text { Co-evolution a } \\
\text { stronger predictor } \\
\text { than evolution (P1) }\end{array}$ & $\begin{array}{l}\text { Firm-Environment } \\
\text { Evolution a stronger } \\
\text { predictor than co- } \\
\text { evolution since } \\
\text { firms established } \\
\text { with own strategic } \\
\text { direction (P2) }\end{array}$ & $\begin{array}{l}\text { Firm-Environment } \\
\text { Evolution a stronger } \\
\text { predictor than co- } \\
\text { evolution since } \\
\text { firms established } \\
\text { with own strategic } \\
\text { direction (P2) }\end{array}$ & $\begin{array}{l}\text { Firm-Environment } \\
\text { Firm-Firm } \\
\text { Firm-alliance } \\
\text { Co-evolution } \\
\text { occurring through } \\
\text { strategic alliances; } \\
\text { alliances essential } \\
\text { to maintain } \\
\text { viability (P3) }\end{array}$ \\
\hline $\begin{array}{l}\text { Unit of } \\
\text { change and } \\
\text { selection } \\
\text { proposed }\end{array}$ & $\begin{array}{l}\text { Selection unit } \\
\text { variable and can } \\
\text { include firms, dyads } \\
\text { and networks (P1) }\end{array}$ & $\begin{array}{l}\text { Unit of selection } \\
\text { more focused on } \\
\text { individual firms } \\
\text { (P2) }\end{array}$ & $\begin{array}{l}\text { Growing trend for } \\
\text { selection to involve } \\
\text { more than } 1 \text { firm } \\
\text { (P2) }\end{array}$ & $\begin{array}{l}\text { Multiple: Firms, } \\
\text { dyads, supply } \\
\text { chains, alliances. } \\
\text { (P3) }\end{array}$ \\
\hline $\begin{array}{l}\text { Mechanisms } \\
\text { of change } \\
\text { seen }\end{array}$ & $\begin{array}{l}\text { Firm-Environment } \\
\text { Firm - Firm } \\
\text { Firm- Alliance }\end{array}$ & Not studied & Not studied & $\begin{array}{l}\text { Firm-Environment } \\
\text { Firm - Firm } \\
\text { Firm- Alliance }\end{array}$ \\
\hline $\begin{array}{l}\text { Mechanism of } \\
\text { selection }\end{array}$ & $\begin{array}{l}\text { Firms trying to } \\
\text { change unit of } \\
\text { selection to dyadic- } \\
\text { therefore co- } \\
\text { selection and co- } \\
\text { evolution present } \\
\text { P1 supported }\end{array}$ & n.a. & n.a. & $\begin{array}{l}\text { Firms trying to } \\
\text { change unit of } \\
\text { selection to dyadic } \\
\text { - therefore co- } \\
\text { selection and co- } \\
\text { evolution present } \\
\text { P3 supported }\end{array}$ \\
\hline
\end{tabular}

As noted above, extant management theories have been derived from relatively mature manufacturing industries where firms largely compete on an individual basis and are selected for on this basis. This study examined how, and why, firms in emerging and declining industry sectors form and change within strategic alliances. The findings support the idea that co-evolution and co-selection appear to provide a better explanation of firm behaviour that the more traditional approach of evolution and survival of the fittest. 


\section{Limitations and Future Research}

The two industries in this paper came from differing countries, and were both relatively small sample sizes. In addition, the mature middling stages of the life cycle were not addressed. Further research should look at more industries to see if the patterns here were in large, determined by the environment that these firms operated in, or whether the life stage of the industry is, as this study suggests a significant factor in evolutionary and co-evolutionary behaviour. The integration of the lifecycle stage of either the firm or the industry should be further examined to determine if there are generalisable patterns of competition and selection and to determine if evolution or coevolution is a better explanatory for firm survival; this would allow strategy determination to account for the simultaneous change between firms, their environment and if appropriate their cooperative partners.

\section{References}

[1] T.K. Das, B-S. Teng, The dynamics of alliance conditions in the alliance development process, J. Manag. Stud. 39 (5) (2002) 725-746.

[2] M.P. Koza, A.Y. Lewin, The co-evolution of strategic alliances, Organ. Sci. 9 (3) (1999) 255-264.

[3] H.W. Volberda, A.Y. Lewin, Co-evolutionary dynamics within and between firms: from evolution to co-evolution, J. Manag. Stud. 40 (8) (2003) 2111-2135.

[4] I. Wilkinson, L. Young, D. Ladley, Group selection versus individual selection and the evolution of cooperation in business networks, IMP Conference Proceedings, Manchester University, 2007.

[5] J. Wilson and N. Hynes Co-evolution of firms and strategic alliances: theory and empirical evidence, J. Tech. Forecasting and Social Change, 76 (5) (2009) 620-628. [6] A. Pyka, Innovation networks in economics - from the incentive based to the knowledge based approaches. European J. Innov. Manag. 5 (3) (2002) 152-163. [7] R.M. Grant, C. Baden-Fuller, A knowledge accessing theory or strategic alliances, J. Manag. Stud. 41 (1) (2004) 61-83.

[8] T.K. Das, B-S. Teng, A resource-based theory of strategic alliances, J. Manag. 26 (1) (2000) 31-61.

[9] R. Gulati, N. Nohria, A. Zaheer, Strategic networks, Strateg. Manag. J. 21 (3) (2000) 203-215.

[10] B. Kogut, Joint ventures: theoretical and empirical perspectives, Strateg. Manag. J. 9 (4) (1988) 319-332.

[11] P.R. Varadarajan, M.H. Cunningham, Strategic alliances: a synthesis of conceptual foundations, J Acad. Market. Sci. 23 (4) (1995) 282-296. 
[12] A. Parkhe, Understanding trust in international alliances, J. World Bus. 33 (3) (1998) 219-239.

[13] J-F. Hennart, A transaction costs theory of equity joint ventures, Strategic Manag. J. 9 (1998) 361-74.

[14] O.E. Williamson, The Economic Institutions of Capitalism: Firms, Markets, Relational Contracting, New York: Free Press, 1985.

[15] J.B. Barney, Firm resources and sustained competitive advantage, J. Manag. 17 (1) (1991) 99-120.

[16] C. Garcia-Pont, N. Nohria, Local versus global mimetism: the dynamics of alliance formation in the automobile industry, Paper presented at the SMJ Special Issue Conference on Strategic Networks, 1999.

[17] R. Gulati, Network location and learning: the influence of network resources and firm capabilities on alliance formation, Strat. Manag. J. 20 (5) (1999) 397-420.

[18] R. Gulati, M. Gargiulo, Where do inter-organisational networks come from? Am. Journal of Sociology 103 (1999) 177-231.

[19] M. Supphellen, S.A. Haugland, T. Korneliussen, SMEs in search of international strategic alliances: Perceived importance of personal information sources, J. Bus. Res. 55 (9) (2002) 785-795.

[20] M. Huyens, C. Baden-Fuller, F.A.J. Van den Bosch, H.W. Volberda, Co-evolution of firm capabilities and industry, Organ. Stud. 22 (6) (2001) 971-1012.

[21] A.Y. Lewin, H.W. Volberda, Prolegoma on coevolution: a framework for research on strategy and new organizational forms, Organ. Sci. 10 (5) (1999), 519-534.

[22] S. Rodrigues, J. Child, Co-evolution in an institutionalized environment, J. Manag. Studies, 40 (8) (2003) 2137-2162.

[23] Y. Doz, The evolution of cooperation in strategic alliances: initial conditions or learning processes? Strat. Manag. J. 17 (1) (1996) 55-83.

[24] P.S. Ring, and A.H. van de Ven, Structuring cooperative relationships between organizations. Strat. Manag. J. 13 (1994) 483-498.

[25] S. Klepper, Entry, exit, growth and innovation over the product life cycle, American Economic Review, 86 (1996), 562-583.

[26] J. Boyan, G.M. MacDonald, The life cycle of a competitive industry, The Journal of Political Economy, 102 (2) (1994) 322.

[27] J. A. Schumpeter, Capitalism, Socialism and Democracy, New York, Harper and Row, 1942.

[28] B. Javanovic, Selection and the evolution of industry, Econometrica, 50 (3) (1982), 649-670.

[29] S.G. Winter, Schumpeterian competition under alternative technological regimes, Journal of Economic Behaviour and Organisation, 5, (1984) 287-320, [30] J.G. Covin, D.P. Slevin, Strategic management of small firms in hostile and benign environments, Strat. Manag. J. 10 (1) (1989) 75-87. 
[31] F.A.J. Van den Bosch, H.W. Volberda, M. de Boer, Coevolution of Firm Absorptive Capacity and Knowledge Environment: Organizational Forms and Combinative capabilities, Organ. Sci. 10 (5) (1999), 551-568.

[32] J. Rice, P. Galvin, Alliance patterns during industry life cycle emergence: the case of Ericsson and Nokia, Technovation, 26 (2006) 384-395.

[33] J. Baum, Ecological Approaches to Organizations, Sage Handbook for Organization Studies, pp. 55-110, 2006.

[34] H.E. Aldrich, M. Reuf, Organizations Evolving (2nd edition), Thousand Oaks, CA:

Sage Publications, 2006.

[35] D.L. Deeds, C.W.L. Hill, An examination of opportunistic action with research alliances: evidence from the biotechnology industry, J. Bus. Vent. 14 (2) (1999), 141163.

[36] M.H. Meyer, E.B. Roberts, Focusing product technology for corporate growth, Sloan Manag. Rev. 29 (1988) 7-16.

[37] Hynes, N and Mollenkopf, D.A. Capturing strategic alliance outcomes: an analysis of motives, objectives and outcomes, Int. J. Tech. Manag. 43 (1-3) (2008) 194-211.

[38] M. E. Porter, Competitive Advantage, The Free Press, New York, 1985.

[39] C. Bowman, D. Faulkner, Competitive and Corporate Strategy, Irwin, 1996.

[40] J. A. C. Baum, J. V. Singh, Evolutionary Dynamics of Organisations, New York: Oxford University Press, 1994.

[41] J.W. Cresswell, Qualitative Inquiry and Research Design: Choosing Among Five Traditions, Thousand Oaks, Calif.: Sage Publications, 1998.

[42] A.M. Riege, Validity and reliability tests in case study research: a literature review with "hands-on" applications for each research phase, Qualitative Market Research: An International Journal, 6 (2) (2003) 75-86.

[43] M. Q. Patton, Qualitative Research and Evaluation Methods, Thousand Oaks, Calif.: Sage Publications, 2002.

[44] K.M Eisenhardt, Building Theories from Case study Research, Academy of Management Review, 14 (4) (1989) 532-550.

[45] Innovation Dynamics, Queensland Biotechnology Report, 2006.

[46] Keynote, Supermarkets and Superstores, Market Report, Key Note Limited, London, 2000.

[47] Mintel, Fresh Fruit and Vegetables - UK, Mintel International Group, London, 2005.

[48] DEFRA, Farm Incomes in the UK, Department for the Environment Food and Rural Affairs (DEFRA), 2008.

[49] J. Bleeke, D. Ernst, The way to win in cross-border alliances, Harv. Bus. Rev. 69

(1991) 127-135.

[50] J. Dyer, H. Singh, The relational view: co-operative strategy and sources of interorganisational competitive advantage, Acad. Manage. Rev. 23 (4) (1998) 660-679. 
[51] H.E. Aldrich, C. M. Fiol, Fools rush in? The institutional context of industry creation, Acad. of Manage. Rev. 19 (4) (1994) 645-670.

[52] H. Rao, Certification mechanisms and trust: Reliability competitions in the American automobile industry, 1895-1912, Unpublished paper, Emory University Business School, Atlanta, GA. (1993).

[53] B. McKelvey, Managing Coevolutionary Dynamics, $18^{\text {th }}$ EGOS Conference, Barcelona, Spain, July 4-6, (2002).

[54] M. P. Koza, A.Y. Lewin, The co-evolution of strategic alliances, Organ. Sci., Vol. 9 (3) (1998) 255-264.

[55] A. Ariño, J. de la Torre, Learning from failure: Towards an evolutionary model of collaborative ventures, Organ. Sci., Vol. 9 (3) (1998) 306-325.

[56] B. Gomes-Casseres, Alliance strategies of small firms, Small Bus. Econ., Vol. 9 (1) 1996 33-44. 